\title{
PENGARUH KOMPENSASI TERHADAP PRODUKTIVITAS KERJA PEGAWAI PADA BADAN PENANGULANGAN BENCANA DAERAH KABUPATEN PESISIR BARAT
}

\author{
Edi Firdaus Siregar ${ }^{(1)}$, Husna Purnama ${ }^{(2)}$, Sodirin $^{(3)}$ \\ Fakultas Ekonomi Universitas Sang Bumi Ruwa Jurai \\ firdaus_siregar@gmail.com,husna.purnama@fe.saburai.ac.id,sodirin@fe.saburai.ac.id
}

\begin{abstract}
Abstrak. Kompensasi sangat mempengaruhi kinerja pegawai, jika kompensasi yang diberikan oleh dinas/satker sesuai dengan pekerjaan yang dikerjakan oleh pegawai, maka kinerja pegawai dapat meningkat. Produktifitas adalah: "Suatu sikap mental yang selalu mempunyai pandangan bahwa mutu kehidupan hari ini harus lebih baik dari kemarin dan hari esok harus lebih baik dari hari ini. Identifikasikan masalah :Produktivitas kerja pegawai Badan Penanggulangan Bencana Daerah (BPBD) yang masih rendah, Kompensasi yang di dapat belum sesuai dengan kebutuhan pegawai Badan Penanggulangan Bencana Daerah (BPBD) Kabupaten Pesisir Barat Perumusan masalah: Apakah Kompensasi berpengaruh Terhadap Produktivitas kerja Pegawai Pada Badan Penanggulangan Bencana Daerah (BPBD) Kabupaten Pesisir Barat. Tujuan dari penelitian: Untuk mengetahui Pengaruh Kompensasi Terhadap Produktivitas kerja Pegawai Pada Badan Penanggulangan Bencana Daerah (BPBD) Kabupaten Pesisir Barat. Metode Penelitian yang digunakan metode penelitian kualitatif dan kuantitatif dengan pengambilan data secara populasi sebanyak 24 orang pegawai. Pengujian dilakukan dengan menggunakan uji t pada tingkat keyakinan signifikansi $\alpha 0.05$. Dari hasil tabel 4.8 dapat diketahui bahwa tingkat signifikansi sebesar $0.006<0.05$ dengan nilai thitung > ttabel yaitu $3.011>1,71714$, dengan demikian hipotesis diterima yang berarti modal kompensasi berpengaruh terhadap produktifitas kerja pada Badan Penanggulangan Bencana Daerah (BPBD) Kabupaten Pesisir Barat. Hasil pengujian bahwa nilai R square sebesar 0,292. Nilai R square ini menunjukkan bahwa besarnya kontribusi variabel independen terhadap variabel dependen adalah sebesar $29,20 \%$, sedangkan sisanya sebesar $71,80 \%$ ditentukan oleh variabel lain yang tidak teridentifikasi dalam penelitian ini.
\end{abstract}

Kata kunci: Pegawai, Kompensasi, Kinerja, Disiplin.

\section{PENDAHULUAN}

Sumberdaya manusia merupakan aset yang dapat meningkatkan keberhasilan organisasi. Kemampuan sumberdaya manusia merupakan kunci utama untuk mampu menghadapi persaingan dalam era globalisasi, kemampuan ini sering disebut keunggulan kompetitif. Paradigma baru dalam pengelolaan kegiatan organisasi adalah pendayagunaan sumberdaya manusia. Hal tersebut di cerminkan dari peran sumberdaya manusia dalam kegiatan organisasi.

Kompensasi sangat mempengaruhi kinerja pegawai, jika kompensasi yang diberikan oleh perusahaan sesuai dengan pekerjaan yang dikerjakan oleh pegawai, maka kinerja pegawai dapat meningkat. Menurut Husein Umar dalam Sunyoto (2012 : 30) menyatakan bahwa salah satu cara manajemen untuk meningkatkan kinerja para pegawai adalah melalui kompensasi. Kompensasi di definisikan sebagai sesuatu yang di terima oleh pegawai sebagai balas jasa untuk jasa mereka. Kinerja dianggap sesuatu yang penting, baik bagi organisasi maupun bagi pegawai itu sendiri. Hal ini dikarenakan apabila kinerja dari pegawai meningkat atau relatif bagus, maka pegawai itu sendiri akan mendapatkan kompensasi atau balas jasa yang setimpal dengan kinerja dari 
pegawai tersebut. Tentu saja kegiatankegiatan dapat diselesaikan tepat waktu dan tujuan dapat dicapai dengan baik. Apabila seorang pegawai menganggap bahwa kompensasi yang diberikan Untuk menciptakan suasana yang kondusif tentunya tidak dengan begitu saja dapat diwujudkan. Organisasi harus mampu memberikan motivasi kepada para pegawainya agar terdorong untuk melaksanakan tugasnya dan dapat meningkatkan produktifitas secara menyeluruh.

\begin{tabular}{cccr}
\multicolumn{1}{c}{ Salah } & satu & jalan & untuk \\
memotivasi & pegawai & agar & dapat \\
diberdayakan & seefektif & dan & seefisien
\end{tabular} mungkin guna meningkatkan produktivitas adalah dengan jalan pemberian kompensasi kepada mereka. Hal ini diharapkan dapat membentuk suatu pola hubungan baik antara para pegawai dimana para pegawai akan bahwa oraganisasi tempat dimana mereka bekerja bisa memahami serta mengetahui kebutuhan hidup yang menjadi pemicu mengapa mereka bekerja.

Dari sudut pandang organisasi, pemberian kompensasi atau balas jasa merupakan suatu biaya yang harus dikeluarkan kepada para pegawinya. Oleh karena itu pihak organisasi harus melakukan suatu penilaian yang teliti mengenai produktifitas kerja yang dihasilkan oleh tiap-tiap pegawai tersebut.Hal tersebut dilaksanakan oleh pihak organisasi karena perusahaan tersebut menghendaki adanya suatu produktifitas kerja yang maksimal dari biaya kompensasi yang mereka keluarkan.

Sedangkan apabila dilihat dari sudut pandang pegawai, kompensasi dipandang sebagai alat untuk mempertahankan kelangsungan hidupnya secara ekonomis untuk memenuhi kebutuhan hidupnya karena merupakan suatu kenyataan yang tidak dapat disangkal bahwa motivasi dasar bagi kebanyakan orang menjadi pegawai dalam suatu organisasi adalah untuk mencari nafkah.

Bila Perumusan kebijaksanaan kompensasi telah tepat, baik dalam aspek keadilan maupun kelayakannya maka pegawai akan merasa puas dan termotivasi untuk melaksanakan berbagai kegiatan yang berhubungan dengan pencapaian tujuan organisasi. Sebaliknya, bila rasa keadilan dan kelayakan tidak terpenuhi akan menyebabkan pegawai mengeluh, menimbulkan ketidakpuasan kerja yang kemudian berdampak pada kemerosotan semangat kerja yang pada gilirannya menyebabkan produktifitas kerja pegawai akan merosot pula.

Peningkatan produktifitas tersebut dapat meningkatkan pula produktifitas organisasi secara keseluruhan, yang dapat menjadi tolak ukur Keberhasilan seorang pegawai. Ketika pemberian kompensasi berjalan dengan lancar dan sesuai dengan perencanaannya maka tahapan selanjutnya yang diharapkan akan terjadi adalah memotivasi pegawai untuk meningkatan produktifitas kerja. Ketika produktifitas pegawai telah tercapai maka organisasi dapat mengukur sejauh mana peningkatan produktifitas kerja yang mereka capai. Hal inilah yang menjadi alur dasar penelitian yang akan dikembangkan oleh penulis, dimana penulis menduga terdapat pengaruh antara pemberian kompensasi dan produktivitas kerja pegawai.

Berdasarkan fenomena di atas, maka penulis bermaksud melakukan penelitian secara lebih mendalam mengenai kompensasi terhadap produktifitas kerja pegawai yang dituangkan dalam skripsi yang berjudul: "Pengaruh Kompensasi Terhadap Produktivitas Kerja Pegawai Pada Badan Penanggulangan Bencana Daerah (BPBD) Kabupaten Pesisir Barat". 


\section{KAJIAN TEORI}

\section{Pengertian Kompensasi}

Kompensasi merupakan salah faktor penting dan menjadi perhatian pada banyak organisasi dalam mempertahankan dan menarik sumber daya manusia yang berkualitas. Menurut I Komang Ardana (2012 : 153) "Kompensasi adalah segala sesuatu yang diterima oleh karyawan sebagai balas jasa atas kontribusinya kepada perusahaan atau organisasi" . Kompensasi dapat berupa gaji dan upah. Kompensasi bersifat financial dan non financial, sedangkan menurut Hasibuan (2012 : 254) "Kompensasi merupakan imbalan yang dibayarkan kepada karyawan atas jasa yang mereka sumbangkan pada pekerjaannya".

Menurut Hasibuan (2012 : 118) "Kompensasi adalah semua pendapatan yang berbentuk uang, barang langsung atau tidak langsung yang diterima karyawan sebagai imbalan atas jasa yang diberikan kepada perusahaan". Menurut Hasibuan (2012 : 254) "Kompensasi merupakan salah satu faktor penting dan menjadi perhatian pada banyak organisasi dalam mempertahankan dan menarik sumberdaya manusia yang berkualitas".

\section{Fungsi dan Tujuan Kompensasi}

Menurut I Komang Ardana dkk (2012 : 154) Fungsi Dan Tujuan Pemberian Kompensasi adalah sebagai berikut :

1. Ikatan kerja sama, dengan pemberian kompensasi maka terjalinnya ikatan kerjasama formal antara majikan dengan karyawan, disitu karyawan harus mengerjakan tugas-tugas dengan baik sedangkan pengusaha atau majikan wajib membayar kompensasi itu sesuai perjanjian .

2. Kepuasan kerja, dengan balas jasa karyawan akan dapat memenuhi kebutuhan fisik, sosial, egoistiknya sehingga karyawan memperoleh kepuasan kerja dari jabatan itu.

3. Pengadaan efiktif, jika program kompensasi ditetapkan cukup besar maka pengadaan karyawan yang qualified untuk perusahaan itu akan lebih mudah.

4. Motivasi,jika balas jasa yang di berikan cukup besar, manjer akan lebih mudah memotivasi bawahannya.

5. Stabilitas karyawan, dengan program kompensasi atas prinsip adil dan layak serta eksternal konsistensi yang kompetitif maka stabilitas karyawan lebih terjamin karena turn over relatif kecil.

6. Disiplin, dengan pemberian balas jasa yang cukup maka disiplin karyawan semakin baik, mereka akan menyadari serta mentaati peraturan yang berlaku.

7. Pengaruh serikat buruh, dengan program kompensasi yang baik berpengaruh dapat dihindarkan dan karyawan akan berkonsentrasi pada pekerjaannya.

8. Pengaruh pemerintah, jika program kompensasi sesuai dengan undang undang perburuhan yang berlaku (seperti batas upah minimum maka intervensi pemerintah dapat dihindarkan.

\section{Pengertian Produktivitas Kerja}

Pengertian produktifitas di atas, dapat disimpulkan menjadi suatu filosofi dan sikap mental yang timbul dari motivasi yang kuat dari masyarakat, yang secara terus-menerus berusaha meningkatkan kualitas kehidupan. Menurut para ahli produktifitas kerja yaitu:

Menurut George J. Washin Produktifitas mengandung dua konsep utama, yaitu efisiensi dan efektivitas. Efisiensi mengukur tingkat sumber daya, baik manusia, keuangan, maupun alam 
yang dibutuhkan untuk memenuhi tingkat pelayanan yang dikehendaki, efektivitas mengukur hasil mutu pelayanan yang dicapai.

Sedarmayanti (2001:57) menyatakan bahwa produktifitas adalah: "Suatu sikap mental yang selalu mempunyai pandangan bahwa mutu kehidupan hari ini harus lebih baik dari kemarin dan hari esok harus lebih baik dari hari ini."

M.Sinungan （ 2009:12) mendefenisikan produktifitas sebagai:

"Hubungan antara hasil nyata maupun fisik (barang-barang dan jasa) dengan masukan yang sebenarnya."

\section{Faktor Faktor yang Mempengaruhi Produtktifitas kerja}

Menurut Pandji Anoraga, ada 10 faktor yang sangat diinginkan oleh para karyawan untuk meningkatkan produktivitas kerja karyawan, yaitu:

1. Pekerjaan yang menarik

2. Upah yang baik

3. Keamanan dan perlindungan dalam pekerjaan

4. Etos kerja dan

5. Lingkungan atau sarana kerja yang baik

6. Promosi dan perkembangan diri mereka sejalan dengan

7. Perkembangan perusahaan

8. Merasa terlibat dalam kegiatan-kegiatan organisasi

9. Pengertian dan simpati atas persoalanpersoalan pribadi

10. Kesetiaan pimpinan pada diri sipekerja

11. Disiplin kerja yang keras

(Pandji Anoraga (2005: 56-60)

\section{METODE PENELITIAN}

\section{Objek Penelitian}

Objek penelitian ini adalah pegawai pada Badan Penanggulangan Bencana Daerah (BPBD) Kabupaten Pesisir Barat, yang beralamat di Jln Lintas Barat Pekon Way Redak Kecamatan Pesisir Tengah Krui Kabupaten Pesisir Barat. Penelitian ini di laksanakan dari bulan Juni sampai dengan Juli 2019.

\section{Metode dan Teknik Pengumpulan Data}

Data yang di perlukan dalam penelitian dapat berupa data sekunder dan data primer yang di kumpulkan dengan cara sebagai berikut :

a. Data primer yaitu jenis data yang dikumpulkan dan diolah langsung dari objek penelitian yaitu dari Badan Penanggulangan Bencana Daerah (BPBD) Kabupaten Pesisir Barat seperti catatan, agenda, dokumen dan lain-lain.

b. Data Sekunder yaitu data yang bersumber dari luar objek penelitian seperti buku-buku, majalah, yang berkaitan dengan masalah penelitian ini.

Langkah-langkah pengumpulan data yang penulis lakukan dengan mengadakan penelitian lapangan yaitu : Penelitian yang dilakukan pada Badan Penanggulangan Bencana Daerah (BPBD) Kabupaten Pesisir Barat, adapun teknik yang digunakan dalam pengumpulan data adalah dengan :

1. Observasi, Yaitu mengadakan survey atau pengamatan langsung ke lokasi penelitian.

2. Interview atau wawancara, Yaitu mengadakan tanya jawab langsung dengan pegawai pada Badan Penanggulangan Bencana Daerah (BPBD) Kabupaten Pesisir Barat.

3. Dokumentasi, Yaitu mengumpulkan dan mencatat dokumentasi yang relevan. 
4. Quisioner,Yaitu membuat pertanyaan yang berhubungan dengan varibael penelitian.

\section{Sampel dan Populasi}

Dalam penelitian ini, penulis tidak menggunakan sampel penelitian dikarenakan jumlah pegawai yang ada di Badan Penanggulangan Bencana Daerah (BPBD) Kabupaten Pesisir Barat berjumlah kurang dari 100 orang maka apabila subyeknya kurang dari 100, lebih baik diambil semua sehingga penelitiannya merupakan penelitian populasi. Selanjutnya jika jumlah subyeknya besar, dapat diambil $10 \%$ - $15 \%$ atau $20 \%$ - $25 \%$ atau lebih. Dalam penelitian ini merupakan penelitian sampel dalam penelitian ini penulis menggunakan data populasi seluruh pegawai yang ada yaitu berjumlah 24 orang pegawai

\section{Metode Analisis Data}

Analisis Regresi Linier Sederhana, Analisis ini digunakan untuk meramalkan besarnya pengaruh variabel bebas terhadap variabel terikat. Dengan kata lain analisis ini digunakan untuk mengetahui besarnya pengaruh produktifitas kerja pegawai bila variabel bebas kompensasi berubah. Model matematisnya dengan rumus sebagai berikut:

$$
Y=\alpha+\beta X
$$

Keterangan :

$\mathrm{Y}=$ produktivitas kerja

$\mathrm{X}=$ kompensasi

$\alpha \quad=$ konstanta sisipan

$\beta=$ koefisien regresi yang

dihubungkan dengan variable bebas

(Sugiyono, 2010;75)
Untuk uji t digunakan untuk menguji signifikasi konstanta dari setiap variabel independen. Dengan rumus sebagai berikut (Sugiyono, 2010;78) :

$$
t n=b-\frac{B}{s b}
$$

$\mathrm{B}=$ Regresi parsial yang ditemukan.

$\mathrm{Sb}=$ Standar deviasi standar

$\mathrm{N} \quad=$ Jumlah sampel.\$

$\mathrm{T}=\mathrm{t}_{\text {hitung }}$ yang selanjutnya dibandingkan dengan $t_{\text {tabel}}$.

Kriteria pengujian hipotesis yang diajukan adalah sebagai berikut:

1. Ho: bi $=0$, variabel bebas tidak memberikan pengaruh terhadap variabel terikat.

2. Ha : bi $=0$, variabel bebas memberikan pengaruh terhadap variabel terikat.

Pengujian ini dilakukan dengan tingkat kepercayaan $95 \%$ dan tingkat kesalahan 5\% dengan $\quad d f=(n-k-1)$. Dasar pengambilan keputusannya yaitu

1. Jika probabilitas >0,05 maka H0 diterima dan Ha ditolak.

2. Jika probabilitas $\square 0,05$ maka H0 ditolak dan Ha diterima.

Koefisien determinasi dimaksudkan untuk mengetahui tingkat ketepatan paling baik dalam analisa regresi dimana hal yang ditunjukan oleh besarnya koefisien determinasi (R2) antara 0 (nol) dan 1 (satu). Koefsien determinasi (R2) nol variabel independen sama sekali tidak berpengaruh terhadap variabel dependen.

Apabila koefisien determinasi semakin mendekati satu, maka dapat dikatakan bahwa variabelindependen berpengaruh terhadap variabel dependen, Selain itu koefisien determinasi (R2) dipergunakan untuk mengetahui prosentase 
perubahan variabel tidak bebas (Y) yang disebabkan oleh variabel bebas (X).

\section{HASIL DAN PEMBAHASAN}

\section{Pengujian Regresi Sederhana}

Dari pengolahan data statistik maka diperoleh persamaan regresi linier berganda sebagai berikut :

Tabel Hasil Uji Regresi Linear Sederhana

\begin{tabular}{|c|c|c|c|c|c|c|c|}
\hline \multirow{4}{*}{ Model } & \multicolumn{7}{|c|}{ Coefficientsa } \\
\hline & \multirow{2}{*}{\multicolumn{2}{|c|}{$\begin{array}{l}\text { Unstandardized } \\
\text { Coefficients }\end{array}$}} & \multirow{2}{*}{$\begin{array}{l}\text { Standardi|t } \\
\text { zed } \\
\text { Coefficie }\end{array}$} & & \multirow{3}{*}{ Sig. } & \multirow{2}{*}{\multicolumn{2}{|c|}{$\begin{array}{l}\text { Collinearity } \\
\text { Statistics }\end{array}$}} \\
\hline & & & & & & & \\
\hline & $B$ & Errot & Beta & & & $\begin{array}{l}\text { Tolera } \\
\text { nce }\end{array}$ & VIF \\
\hline \multirow{2}{*}{$\begin{array}{l}\text { (Constan } \\
\text { t) } \\
1 \\
\text { Kompens } \\
\text { asi }\end{array}$} & 22,106 & 7,168 & & 3,084 &, 005 & & \\
\hline & 508 & 169 &, 540 & 3,011 &, 006 & $1,000 \mid$ & 1,000 \\
\hline
\end{tabular}

a. Dependent Variable: Produktivitas

Sumber: Data primer yang telah diolah, 2019

Berdasarkan tabel diatas dapat
dilihat persamaan regresi
sederhana sebagai berikut :

$$
Y=22,106+0,508(X)
$$

1. Konstanta $(\alpha)$, Nilai konstanta yang diperoleh sebesar 22,106, hal ini berarti bahwa jika variabel independen (kompensasi) adalah bernilai nol, maka besarnya produktifitas kerja yang terjadi adalah 22,106.

2. Koefisien regresi $(\beta)$, Nilai koefisien regresi variabel kompensasi (X) sebesar 0,508, hal ini menunjukkan bahwa setiap kenaikan satu satuan modal akan mengakibatkan kenaikan produktifitas kerja sebesar 0,508.

\section{Uji Hipotesis (Uji Statistik t)}

Pengujian ini dilakukan untuk menjawab model kelayakan hipotesis penelitian. Pengujian dilakukan dengan menggunakan uji $\mathrm{t}$ pada tingkat kepercayaan 95\% atau $\alpha$ sebesar 0.05 dari hasil output SPSS yang diperoleh, apabila $t_{\text {hitung }}>t_{\text {tabel }}$. Maka model dinyatakan layak digunakan dalam penelitian ini dan sebaliknya apabila $t_{\text {hitung }}<t_{\text {tabel }}$, maka model dikatakan tidak layak, atau dengan signifikan (Sig) 0.05 maka model dinyatakan layak digunakan dalam penelitian ini dan sebaliknya apabila signifikan (Sig) > 0.05 maka model dinyatakan tidak layak digunakan.

Tabel Hasil Uji Hipotesis

\begin{tabular}{|c|c|c|c|c|c|c|c|}
\hline \multirow{4}{*}{ Model } & \multicolumn{7}{|c|}{ Coefficientsa } \\
\hline & \multirow{2}{*}{\multicolumn{2}{|c|}{$\begin{array}{l}\text { Unstandardized } \\
\text { Coefficients }\end{array}$}} & \multirow{3}{*}{$\begin{array}{l}\text { Standardi } \\
\text { zed } \\
\text { Coefficie } \\
\text { ntc } \\
\text { Beta }\end{array}$} & & \multirow{3}{*}{ Sig. } & & \\
\hline & & & & & & \multicolumn{2}{|c|}{$\begin{array}{l}\text { Collinearity } \\
\text { Statistics }\end{array}$} \\
\hline & B & $\begin{array}{l}\text { Std. } \\
\text { Error }\end{array}$ & & & & $\begin{array}{l}\text { Tolera } \\
\text { nce }\end{array}$ & VIF \\
\hline \multirow{2}{*}{$\begin{array}{l}\text { (Constan } \\
\text { t) } \\
1 \\
\text { Kompens } \\
\text { asi }\end{array}$} & 22,106 & 7,168 & & 3,084 &, 005 & & \\
\hline & 508 &, 169 &, 540 & 3,011 &, 006 & 1,000 & 1,000 \\
\hline
\end{tabular}

a. Dependent Variable: Produktivitas

Sumber: Data primer yang telah diolah, 2019

Pengujian pada tabel dapat menjawab hipotesis yang menyatakan "Kompensasi berpengaruh terhadap produktifitas kerja." Pengujian dilakukan dengan menggunakan uji $t$ yang menunjukkan bahwa kompensasi berpengaruh terhadap produktifitas kerja. Pengujian dilakukan dengan menggunakan uji $\mathrm{t}$ pada tingkat keyakinan signifikansi $\alpha 0.05$. Dari hasil tabel dapat diketahui bahwa tingkat signifikansi sebesar $0.006<0.05$ dengan nilai $t_{\text {hitung }}>\mathrm{t}_{\text {tabel }}$ yaitu 3,011 > 1.71714 . dengan demikian hipotesis diterima yang berarti modal Kompensasi berpengaruh terhadap Produktifitas kerja pada Badan 
Penanggulangan Bencana Daerah

Kabupaten pesisir barat.

\section{KESIMPULAN DAN SARAN}

\section{Kesimpulan}

Berdasarkan hasil penelitian dan pembahasan yang sudah dilakukan, maka hal yang dapat disimpulkan bahwa:

Hasil pengujian bahwa nilai $R$ square sebesar 0.292. Nilai $R$ square ini menunjukkan bahwa besarnya kontribusi variabel independen terhadap variabel dependen adalah sebesar 29,20\%, sedangkan sisanya sebesar $71,80 \%$ ditentukan oleh variabel lain yang tidak teridentifikasi dalam penelitian ini. nilai signifikan sebesar 5\%. Hal ini menunjukkan jika nilai signifikan kurang atau sama dengan 0.05 maka model pengujian ini layak digunakan dan jika nilai signifikan lebih dari 0.05 maka model pengujian ini tidak layak digunakan. nilai signifikansi sebesar 0.006 lebih kecil dari 0.05. Hipotesis yang menyatakan "Kompensasi berpengaruh terhadap Produktifitas kerja." Pengujian dilakukan dengan menggunakan uji $t$ yang menunjukkan bahwa Kompensasi berpengaruh terhadap Produktifitas kerja. Pengujian dilakukan dengan menggunakan uji $\mathrm{t}$ pada tingkat keyakinan signifikansi $\alpha$ 0.05. Dari hasil diketahui bahwa tingkat signifikansi sebesar $0.006<0.05$ dengan nilai thitung $>$ ttabel yaitu $3.011>1.71714$, dengan demikian hipotesis diterima yang berarti modal kompensasi berpengaruh terhadap produktifitas kerja.

\section{Saran}

Berdasarkan hasil simpulan penelitian yang telah dijelaskan, maka beberapa hal yang bisa menjadi masukan bagi Badan
Penanggulangan Bencana Daerah

Kabupaten Pesisir Barat antara lain:

1. Badan Penanggulangan Bencana Daerah Kabupaten Pesisir Barat hendaknya mempertimbangan pemberian kompensasi dalam bentuk reward yang diberikan kepada pegawainya agar mereka semakin bersemangat untuk bekerja lebih baik.

2. Badan Penanggulangan Bencana Daerah Kabupaten Pesisir Barat hendaknya memberikan tambahan insentif yang sesuai kepada prestasi kerja staf/pegawainya sehingga dapat bekerja dengan baik sesuai produktivitas dan semangat kerjanya

3. Badan Penanggulangan Bencana Daerah Kabupaten Pesisir Barat hendaknya memberikan rewand kepada pegawainya sesuai dengan kemampuan dan kualitas yang dimiliki sesuai dengan kinerjanya.

\section{DAFTAR PUSTAKA}

Algifari. 2008. Metode Penelitian Bisnis. Cetakan Ke-15. Bandung: CV Alfabeta

Arikunto, Suharsimi. 2010. Prosedur Penelitian, Suatu Pendekatan Praktek. Cetakan Kesebelas Edisi Revisi IV. Jakarta: . PT. Rineka Cipta

Budiyono. 2012. Manajemen Sumber Daya Manusia. Jakarta: Erlangga. Daft,

Dina, Afriyanti.2016. Analisis Kompensasi Terhadap Produktivitas Kerja Pada Kantor. Bandar Lampung: Pelayanan Pajak Prama

Ferdinand, 2006. Manajemen Sumber Daya Manusia. Jakarta: Elex Media Kompetindo. 
Hasibuan, 2012. Organisasi dan Motivasi. Jakarta: PT. Bumi Aksara. Jatmiko.

Husein Umar dalam Sunyoto. 2012. Manajemen Sumber Daya Manusia Strategik. Jakarta: Ghalia Indonesia.

Ardana,I Komang. 2012. Manajemen Sumber Daya Manusia. Edisi 4. Yogyakarta: BPFE.

M.Sinungan, 2009. Manajemen Sumber Daya Manusia.Jakarta: Penerbit Yayasan Gunung Agung.

Soeratno (dalam Purnamasari). 2008. Psikologi Islami: Seri Sumber Daya Manusia.Yogjakarta: Liberty.

Sugiyono, 2010. Metode Penelitian Bisnis. Cetakan Ke- 15. Bandung: CV.Alfabeta.

Gibson James L, 2000 Perilaku Organisasi. Edisi ke 5.Jakarta: Erlangga,

Handoko, T. Hani. 2000. Manajemen Personalia dan Manajemen Sumber Daya Manusia. Yogyakarta: BPFEYogyakarta. 